\title{
STRATEGI PENGEMBANGAN USAHA KERAJINAN PERAK DENGAN METODE ANALISIS SWOT PADA USAHA SSS SILVER
}

\author{
Putu Satya Ary Narendra ${ }^{1}$ \\ I Gusti Ayu Ketut Sri Ardani²
}

${ }^{1,2}$ Fakultas Ekonomi dan Bisnis Universitas Udayana(Unud), Bali, Indonesia email: putuhendra1012@gmail.com

\begin{abstract}
ABSTRAK
Tujuan dari penelitian ini adalah untuk mengetahui faktor dominan dari kekuatan, kelemahan, peluang serta ancaman pada usaha kerajinan perak SSS Silver dalam menjalankan usahanya dan menentukan strategi pemasaran yang dapat diterapkan pada usaha kerajinan perak SSS Silver dalam rangka mengembangkan usahanya. Jumlah responden yang merupakan pihak manajemen SSS Silver yang menjadi sampel penelitian adalah sebanyak 3 orang. Teknik analisis yang digunakan adalah analisis SWOT. Hasil penelitian ini menunjukkan bahwa faktor internal dominan yang mempengaruhi usaha kerajinan perak SSS Silver dalam menjalankan operasional perusahaannya adalah faktor kekuatan, sedangkan faktor eksternal yang dominan adalah faktor peluang usaha yang dimiliki SSS Silver. Berdasarkan hasil analisis SWOT, maka strategi yang tepat digunakan oleh usaha kerajinan perak SSS Silver adalah model strategi SO yaitu strategi yang menggunakan kekuatan (Strength) dan dengan memanfaatkan peluang (Opportunies).
\end{abstract}

Kata Kunci: kerajinan perak, strategi pengembangan, SSS Silver, SWOT

\begin{abstract}
The purpose of this research is to find out the dominant factors of strengths, weaknesses, opportunities and threats to SSS Silver's silvercraft business in running its business and determine marketing strategies that can be applied to SSS Silver silvercraft business in order to grow its business. The number of respondents who were the management of SSS Silver who sampled the research was 3 people. The analysis technique used is SWOT analysis. The results of this study show that the dominant internal factor affecting SSS Silver's silver craft business in running its company's operations is the strength factor, while the dominant external factor is the business opportunity factor that SSS Silver has. Based on the results of SWOT analysis, the right strategy used by SSS Silver silvercraft business is so strategy model that is a strategy that uses strength and by utilizing opportunities (Opportunies).

Keywords: silver craft, development strategy, SSS Silver, SWOT.
\end{abstract}




\section{PENDAHULUAN}

Pemerintah Indonesia saat ini berusaha meningkatkan kemampuan industri kecil dan menengah (IKM) sebagai bentuk implementasi dari pengembangan ekonomi lokal dan daerah. Terutama keberadaan industri kecil di banyak negara berkembang mampu memberikan kontribusi mencapai 30\% - 60\% dari seluruh penduduk perkotaan (Permadi, 2015). Untuk mendukung hal tersebut dibutuhkan sebuah strategi yang dilaksanakan secara simultan. Strategi yang tepat akan memberikan dampak positif terhadap perkembangan industri secara berkelanjutan (Pebrianti \& Muta'ali, 2017).

Secara umum IKM memberikan kontribusi yang signifikan terhadap perekonomian nasional. Menurut Hoiron et al. (2019), Industri Kecil Menengah (IKM) memegang peranan penting dalam kemajuan perekonomian suatu Negara, semakin berkembangnya IKM di suatu Negara maka akan meningkatkan perekonomian di Negara tersebut. Sehingga pemerintah harus memberikan perhatian khusus terhadap tumbuh dan kembangnya IKM yang ada di Indonesia. Salah satu IKM yang ada di Indonesia adalah industri kerajinan perak. Sampai saat ini perkembangan industri perak masih belum begitu optimal, sehingga perlu dilakukan analisis daya saing di masing-masing sentra industri perak agar sentra industri perak dapat terus tumbuh dan berkembang, dengan cara melakukan perumusan strategi menggunakan analisi SWOT. Hasil penelitian serupa oleh Yusandipta (2014) juga menyatakan bahwa perkembangan dunia industri yang pesat menuntut suatu industri untuk dapat mengidentifikasikan kemampuan perusahaan dan mempunyai strategi peningkatan dalam pengembangan bisnisnya, sehingga perlu membentuk strategi pengembangan bisnis yang paling tepat diterapkan saat ini oleh usaha kerajinan perak agar dapat memanfaatkan peluang dan mengantisipasi ancaman yang ada dengan mendayagunakan kekuatan dan mengantisipasi kekurangan perusahaan melalui analisis SWOT.

Penelitian serupa oleh Hoiron et al. (2019)menyatakan bahwa strategi pengembangan IKM dapat dilakukan menggunakan strategi pengembangan melalui analisis matriks SWOT. Analisis SWOT dapat membantu para pelaku bisnis untuk menganalisa bagaimana strategi bisnisnya harus dijalankan. Pelaku bisnis harus dapat menentukan strengths atau kekuatan mereka agar dapat di jadikan kunci dalam menjalankan kegiatan bisnisnya, weaknesses atau kelemahan adalah hal yang perlu diwaspadai pelaku bisnis agar tidak mudah terbaca oleh para pesaing. Setiap kegiatan bisnis pasti memiliki kelemahan dan hal inilah yang harus diminimalisir agar tidak menjadi halangan di kemudian hari bagi para pelaku bisnis juga akan memiliki peluang atau opportunities dalam usahanya. Jika peluang tersebut didapat maka pelaku bisnis dapat segera memanfaatkan peluang tersebut untuk menjaring konsumen lebih banyak lagi. Ancaman atau threats adalah halangan utama para pelaku bisnis dalam menjalankan kegiatan bisnisnya (Kurniansah \& Rosida, 2019).

Analisis SWOT merupakan salah satu instrumen analisis yang ampuh apabila digunakan dengan tepat. Maksudnya, keampuhan tersebut terletak pada kemampuan para penentu strategi perusahaan dalam memaksimalkan peranan faktor kekuatan dan pemanfaatan peluang sehingga sekaligus berperan sebagai alat untuk meminimalisasi kelemahan yang terdapat dalam tubuh organisasi dan 
menekan dampak ancaman yang timbul dan harus dihadapi. Jadi sebelum mengambil keputusan, seorang pebisnis harus melakukan analisis SWOT agar keputusan yang diambil tidak salah (Ghazinoory et al., 2011).

Faktor kekuatan dan kelemahan yang sifatnya kritikal berperan sangat penting dalam membatasi usaha pencaharian dalam berbagai alternatif dan pilihan strategi untuk digunakan. Oleh karena itu dengan menggunakan analisis SWOT kompetensi khusus yang dimiliki dan kelemahan yang menonjol dapat dinilai dan dikaitkan dengan berbagai faktor penentu keberhasilan suatu usaha (Zuhri, 2013).

Kekuatan merupakan kompetensi khusus yang terdapat dalam organisasi yang berakibat pada pemilikan keunggulan komparatif oleh unit usaha di pasaran (Nur Irawan, 2017). Hal demikian dikarenakan satuan bisnis memiliki sumber, ketrampilan, produk andalan dan sebagainya yang membuatnya lebih kuat dari para pesaing dalam memuaskan kebutuhan pasar yang sudah direncanakan akan dilayani oleh satuan usaha yang bersangkutan.

Kelemahan merupakan keterbatasan atau kekurangan dalam hal sumber, ketrampilan dan kemampuan yang menjadi penghalang serius bagi penampilan kinerja organisasi yang memuaskan (Maemonah, 2015). Kelemahan itu harus diminimalisir ataupun ditutupi dengan kekuatan yang dimiliki agar konsumen tetap merasa nyaman, hal itu dapat dilakukan dengan memberikan pelayanan yang memuaskan ataupun dengan memberikan diskon untuk menarik pelanggan.

Peluang merupakan berbagai situasi lingkungan yang menguntungkan bagi satu satuan bisnis (Zuhri, 2013). Peluang itu harus dimanfaatkan dengan sebaik mungkin, jangan sampai menyianyiakan peluang yang ada karena kesempatan itu tidak selalu ada. Dengan adanya peluang maka kita dapat mengembangkan ataupun memperluas usaha kita.

Ancaman merupakan faktor-faktor lingkungan yang tidak menguntungkan suatu satuan bisnis (Maemonah, 2015). Jika tidak diatasi ancaman akan menjadi "ganjalan" bagi satuan bisnis yang bersangkutan baik untuk masa sekarang maupun di masa mendatang. Ancaman itu harus dihadapi, agar bisnis yang dijalankan tetap eksis dan dapat berkembang dipasaran. Ancaman biasanya terjadi karena pesaing dapat memberikan hal yang lebih, oleh karena itu kualitas atau mutu produk, jasa pelayanan tetap harus dijaga agar para konsumen tetap loyal (Putro, 2014; Siagian, 2002).

Kemajuan teknologi yang tinggi dan beragamnya kebutuhan konsumen membuat dunia usaha semakin berkembang pesat, termasuk dunia usaha yang berkaitan dengan bidang export perhiasan perak. Persaingan sangat penting bagi keberhasilan atau kegagalan suatu perusahaan, baik persaingan dalam menentukan harga di pasaran, persaingan dalam menentukan varian produk yang menyesuaikan dengan kemauan konsumen seperti inovasi produk perhiasan perak yang mendukung atau implementasi hal-hal yang baru (Rakhman \& Rahayu, 2017). Ukuran keberhasilan perusahaan dalam menerapkan strategi pengembangannya adalah mampu memberikan kepuasan kepada pelanggan. Semakin banyak pelanggan yang menerima produk maka semakin puas dan ini berarti startegi yang di jalankan cukup berhasil (Dwi, 2011).

Kesenian di Bali merupakan salah satu yang diminati oleh wisatawan khususnya kesenian dalam bidang kerajinan yaitu kerajinan perak. Kerajinan 
perak di Bali terdapat pada kabupaten antara lain : Badung, Buleleng, Klungkung, Bangli, dan di Desa Celuk Kabupaten Gianyar. Kerajinan perak ialah seni rupa yang sudah lama di Bali. Kerajinan perak digunakan perlengkapan upacara agama Hindu serta peralatan istana kerajaan. Kerajinan perak pada masa lalu digunakan sebagai kebutuhan spiritual maupun sosial (Sudana, 2013). Kerajinan perak Bali tidak terlepas modernisasi, yang ditransformasi melalui pariwisata. Pariwisata berpengaruh pada kerajinan perak Bali dari aspek bentuk, jenis, fungsi, ataupun maknanya dalam masyarakat (Lestari \& Wirathi, 2016)

Pulau Bali sendiri memiliki ratusan para pengusaha perhiasan perak, mereka memasarkan produknya di art shop masing-masing serta melakukan terobosan dengan memasarkan produknya lewat internet dan mengikuti pameran di kotakota besar dan ke luar negeri. Akhir-akhir ini produksi perhiasan perak dan barang kerajinan lainya sedang mengalami penurunan dimulai dengan krisis Eropa dan disusul Amerika, situasi yang ada saat ini membuat banyak art shop perak mengalami penurunan kunjungan konsumen, hal ini di sebabkan oleh turunnya kunjungan wisatawan serta mahalnya harga produk yang ditetapkan perusahaan, harga produk yang mahal ini dikarenakan para pemilik artshop memberikan jasa servis kepada guide yang mengantarkan tamu ke artshop. Kondisi tersebut menunjukkan banyak artshop yang gulung tikar dan yang masih bisa bertahan mereka menjalin kerjasamanya dengan agen travel lokal untuk mendatangkan tamu ke artshop. Pelaku usaha juga berinovasi dengan memasarkan produknya lewat internet. Kondisi tersebut menyebabkan para pelaku usaha menjadi geram dimana sering terjadinya perang harga di pasaran padahal perhiasan perak hanya di produksi di Indonesia dan di luar negeri sangat sedikit yang memproduksi, ditambah dengan kurang harmonisnya hubungan bisnis para pelaku usaha serta adanya saling mengklaim varian bentuk perhiasan. Situasi ini disebabkan mengingat tipikal pengusaha di Bali tidak mau hidup bersama serta jarang menjalin kerjasama usaha di dalam bidang memasarkan produknya.

Kerajinan perhiasan perak dan emas merupakan salah satu dari 17 jenis usaha kerajinan skala rumah tangga yang berkembang pesat di Kabupaten Gianyar. Desa Celuk, yang lokasinya sangat strategis pada jalur menuju Bali Timur itu merupakan sentra kerajinan perhiasan perak dan emas. Sebuah gagasan muncul pada tahun 2016, yaitu Celuk Jewelry Festival, sebagai momentum bersatu dan bangkitnya Desa Celuk. Event ini membawa misi mengkampanyekan Desa Celuk sebagai salah satu pusat industri kerajinan perak dan emas di Bali. Selain itu, diharapkan dapat mempersatukan masyarakat Desa Celuk agar mampu melangkah bersama dalam meningkatkan perekonomian daerah (Putra \& Ardana, 2016; Warmana \& Widnyana, 2018; Yuniari et al., 2018).

Adapun jumlah Ekspor Perhiasan Perak, Tenaga Kerja, Nilai Tukar, dan Pertumbuhan di Kabupaten Gianyar Provinsi Bali Tahun 2012- 2016 dapat dilihat pada Tabel 1.1 sebagai berikut: 
Tabel 1.

Jumlah Ekspor Perhiasan Perak di Kabupaten Gianyar Provinsi Bali Pada Tahun 2015 - 2018

\begin{tabular}{llllr}
\hline \multirow{2}{*}{$\begin{array}{c}\text { Jumlah Ekspor } \\
\text { per bulan }\end{array}$} & \multicolumn{4}{c}{ Tahun } \\
\cline { 2 - 5 } & $\mathbf{2 0 1 5}$ & $\mathbf{2 0 1 6}$ & $\mathbf{2 0 1 7}$ & $\mathbf{2 0 1 8}$ \\
\hline Januari & $150.521,54$ & $176.551,44$ & $306.778,87$ & $238.907,45$ \\
Feb & $331.078,08$ & $257.101,31$ & $130.024,86$ & $177.462,79$ \\
Mar & $209.295,72$ & $281.759,86$ & $229.133,37$ & $380.827,22$ \\
Apr & $280.121,91$ & $177.518,86$ & $170.107,48$ & $226.459,05$ \\
Mei & $196.681,70$ & $256.631,69$ & $330.028,86$ & $203.178,45$ \\
Jun & $168.719,94$ & $206.980,93$ & $246.331,08$ & $153.671,61$ \\
Jul & $112.751,70$ & $141.272,30$ & $109.385,48$ & $116.800,12$ \\
Agus & $186.024,02$ & $221.540,75$ & $116.982,22$ & $221.844,21$ \\
Sept & $320.883,88$ & $108.764,95$ & $220.194,99$ & $228.303,14$ \\
Okt & $138.667,64$ & $202.931,88$ & $153.916,95$ & $143.667,40$ \\
Nov & $236.890,38$ & $159.694,61$ & $150.839,04$ & $207.535,78$ \\
Des & $118.268,55$ & $245.173,62$ & $175.168,46$ & $141.526,29$ \\
\hline Jumlah Ekspor & $2.449 .905,06$ & $2.435 .922,20$ & $2.338 .891,66$ & $2.440 .183,51$ \\
\hline Pertumbuhan & - & \multicolumn{4}{c}{$-0,57$} & $-3,98$ \\
\hline Sumber $:$ Dinas Perindustrian dan Perdagangan Kabupaten Gianyar, 2020 \\
\end{tabular}

Pada Tabel 1. dapat dilihat jumlah ekspor perhiasan perak yang ada di Kabupaten Gianyar mengalami fluktuasi setiap bulannya. Data menunjukkan terjadi penurunan sebesar $-0,57 \%$ pada tahun 2015 ke 2016 , kemudian mengalami penurunan sebesar $-3,98 \%$ pada tahun 2017 , dan peningkatan terjadi sebesar $4,33 \%$ di tahun 2018. Peningkatan yang terjadi pada tahun 2018 diakibatkan permintaan pasar luar negeri dari negara-negara maju yang terus bertambah.

Fenomena yang terjadi saat ini yaitu adanya tren penurunan ekspor perak. Trend penurunan dari tahun ke tahun ini disebabkan adanya resesi global di negara tujuan ekspor serta adanya perubahan prilaku pembeli perhiasan karena saat ini konsumen didominasi oleh golongan generasi milenial, sehingga terjadi perubahan perilaku yang dulunya membeli perhiasan berubah membelanjakan uangnya untuk makan/minum di cafe/restaurant sesuai gaya hidup (life style) generasi milenial saat ini, dan ada kecenderungan konsumen menggunakan uangnya untuk travelling dan gadget. Alasan lain terjadinya trend penurunan daya beli perak karena pembeli perhiasan saat ini berubah selera membeli model perhiasan yang lebih simple, trendy dan murah. Sedangkan pengrajin perhiasan di Bali masih terpaku pada model design yang etnik dan cenderung sudah tidak digemari lagi.

Permasalahan trend penurunan daya beli perak yang terjadi pada industri kerajinan perak saat ini juga terjadi akibat adanya pandemi Covid-19. Akibat pandemi covid-19 tidak sedikit pelaku usaha yang terdampak, terutama yang berada dan mengandalkan sektor pariwisata. Untuk mampu bertahan, pelaku usaha dituntut inovatif bahkan mengalihkan jenis usaha untuk sementara waktu. Cukup banyak pengusaha kerajinan perak beralih ke usaha kuliner kemasan untuk sementara waktu. Pelaku usaha perak di Celuk, Sukawati Gianyar mengaku bahwa seharusnya bulan ini adalah momen ramainya pameran dan meningkatnya penjualan kerajinan perak. Akibat adanya pandemi tentunya membuat sebagian besar pelaku usaha kerajinan perak tidak bisa berkutik dan mau tidak mau harus 
banting stir mengalihkan jenis usaha yang dibutuhkan masyarakat di tengah pandemi ini (Suranta, 2015).

Terdapat berbagai macam usaha kerajinan perak di Celuk, Sukawati, dan berikut adalah lima besar usaha kerajinan perak yang masih bertahan yang dapat dilihat pada Tabel 2. sebagai berikut:

Tabel 2.

Lima Besar Usaha Kerajinan Perak di Desa Celuk, Sukawati, Gianyar

\begin{tabular}{cll}
\hline No & & Pelaku Usaha Kerajinan Perak \\
\hline 1 & UC Silver & \\
2 & UD. Romo & \\
3 & Cahya Silver & \\
4 & Gaja Silver & \\
5 & SSS Silver & \\
\hline
\end{tabular}

Sumber: Pelaku Usaha Kerajinan Perak di Desa Celuk, Sukawati, 2020

Tabel 2. menunjukkan lima besar pelaku usaha yang mampu bertahan di tengah pandemi Covid-19. Kelima pelaku usaha kerajinan perak tersebut mampu bertahan karena masih memiliki banyak pelanggan dan mampu mempertahankan ekspor produknya. Mengingat lemahnya ekonomi dunia akibat wabah Covid-19 ini, mengakibatkan banyak usaha kerajinan perak yang berhenti memproduksi, namun salah satu yang mampu bertahan adalah SSS Silver, hal ini disebabkan oleh gencarnya usaha SSS Silver memasarkan produk, menambah varian produk, dan mencoba melakukan ekspor produknya (Amelia et al., 2017; Rangkuti, 2004).

Penelitian ini dilakukan pada SSS Silver karena salah satu IKM kerajinan perak yang mampu mempertahankan eksistensinya adalah SSS Silver, yang sampai saat ini selalu menjalankan upaya agar tetap bisa bertahan dan bersaing dengan pengusaha perak lainya. SSS Silver berdiri pada tahun 1998 dan berbentuk badan usaha pada tahun 2005. selama periode tahun 1998 sampai sekarang SSS Silver pernah mengalami pasang surut dimana penjualan yang mengalami peningkatan drastis dan suatu saat bisa menurun, hal ini di pengaruhi oleh situasi ekonomi nasional dan global, di sisi lain juga karena pengaruh harga bahan pokok perak yang mengalami fluktuatif pada masa itu serta menurunnya trend pasar akan minat perhiasan perak nasional dan di luar negeri. SSS Silver sudah banyak mengalami rotasi karyawan yang berada pada bidang produksi, mengingat sebagian besar karyawan produksi perhiasan perak berasal dari luar bali seperti dari jawa timur, dengan kondisi ini membuat pelaku usaha mengalami kesulitan untuk memperoleh karyawan yang handal dan kreatif dalam bidang produksi perhiasan perak ,karena keterbatasan sumber daya manusia juga ikut andil dalam pengaruh menurunya jumlah produksi, mengingat permintaan konsumen dalam jumlah besar tidak selalu bisa terpenuhi dalam waktu dekat.

SSS Silver mempunyai kapasitas produksi rata-rata $50 \mathrm{~kg} / \mathrm{bulan}$ yang terbagi ke beberapa varian produk perhiasan seperti anting-anting (earrings), mata kalung (pendant), cincin (ring), gelang (bracelet), kalung (necklace), jome decoration. Adapun jumlah produksi perhiasan pada SSS Silver pada periode tahun 2017 hingga 2019 dapat dilihat pada Tabel 3. berikut: 
Tabel 3.

Produksi Perhiasan Perak pada SSS Silver Periode 2017-2019

\begin{tabular}{lccc}
\hline \multirow{2}{*}{ Varian Perhiasan Perak } & \multicolumn{3}{c}{ Jumlah Produksi (dalam kg) } \\
\cline { 2 - 4 } & Tahun 2017 & Tahun 2018 & Tahun 2019 \\
\hline anting-anting (earrings) & 130 & 110 & 140 \\
mata kalung (pendant) & 150 & 140 & 160 \\
cincin (ring) & 90 & 80 & 80 \\
gelang (bracelet) & 80 & 100 & 90 \\
kalung (necklace) & 100 & 90 & 90 \\
jome decoration & 70 & 60 & 40 \\
\hline \multicolumn{1}{c}{ Total } & 620 & 580 & 600 \\
\hline
\end{tabular}

Sumber : SSS Silver, 2019

Melihat kondisi perusahaan diatas selama ini SSS Silver belum pernah melakukan analisis terhadap dampak lingkungan baik lingkungan internal maupun lingkungan eksternal. Sehingga SSS Silver tidak dapat menentukan strategi apa yang harus dilakukan untuk menghadapi persaingan dengan Pengusaha Exportir dan Retail Perhiasan Perak lain. Sehingga evaluasi terhadap kekuatan, kelemahan, peluang serta ancaman produk yang di produksi dan sistem yang dijalankan SSS Silver dapat dilakukan dengan menggunakan analisis SWOT. SWOT menempatkan situasi dan kondisi sebagai faktor masukan, yang kemudian di kelompokan menurut kontribusi masing-masing. Kekuatan di pasar sangat berpengaruh terhadap umur kelangsungan usaha Export Dan Retail Perhiasan Perak. Dengan analisis SWOT ini dapat diketahui hal-hal yang dapat dipertimbangkan untuk memperkuat posisi di pasar untuk kemajuan berkembangnya usaha Perhiasan Perak (Ghazinoory et al., 2011; Helms \& Nixon, 2010).

\section{METODE PENELITIAN}

Penelitian ini dilakukan pada SSS Silver di jalan Mengaling, Banjar Tangsub, Celuk, Kec. Sukawati, Kabupaten Gianyar. Populasi dalam penelitian ini adalah seluruh pihak manajemen SSS Silver yang mengetahui informasi tentang aktivitas SSS Silver. Metode penentuan sampel menggunakan sampel jenuh, yaitu semua populasi digunakan sebagai sampel penelitian. Penentuan informan dalam penelitian ini ditujukan kepada pihak manajemen SSS Silver merupakan pihak yang mengambil keputusan dan kebijakan serta pihak yang memiliki informasi yang dibutuhkan untuk penelitian. Adapun informan pada penelitian ini yaitu terdiri dari pemilik usaha yaitu Nyoman Satya Wibawa Upadhana, bagian keuangan yaitu Made Setyawati dan bagian operasional yaitu Ni Made Pastini.

Guna memperjelas variabel yang digunakan dalam penelitian ini serta untuk membahas ruang lingkup permasalahan yang diteliti, maka definisi operasional variabel penelitian ini akan memaparkan indikator strategi pengembangan usaha yang ditinjau dari strategi pemasaran produk STP (Segmenting, Targeting, Positioning) dan dari strategi bauran pemasaran sebagai berikut variabel pemasaran produk yang meliputi Segmentasi pasar (segmenting) dalam penelitian 
ini adalah mengidentifikasi pangsa pasar yang diambil oleh SSS Silver. Pasar sasaran (targeting) dalam penelitian ini adalah memilih segmen pasar yang akan dimasuki oleh SSS Silver. Posisi pasar (positioning) dalam penelitian ini adalah mengidentifikasi penempatan produk di benak konsumen SSS Silver.

Variabel bauran pemasaran produk (products) merupakan segala paket produk SSS Silver yang dapat ditawarkan kepada pelanggan. Distribusi (place) merupakan kegiatan pemasaran yang dilakukan SSS Silver untuk mempermudah penyampaian informasi kepada pelanggan, berupa konten website sebagai representasi kantor online yang bisa diakses oleh calon pembeli (pelanggan). Harga (price) merupakan biaya paket produk yang ditawarkan SSS Silver kepada pembeli (pelanggan). Promosi (promotion) merupakan kegiatan yang dilakukan SSS Silver untuk mengkomunikasikan informasi kepada pelanggan dalam saluran penjualan seperti web, iklan, majalah ataupun media social agar dapat meningkatkan popularitas SSS Silver di benak calon pembeli (pelanggan). Personal (people) merupakan karyawan SSS Silver yang secara langsung atau tidak langsung mempengaruhi konsumen membuat keputusan untuk pembelian. Bukti fisik (physical evidence) merupakan kondisi geografi objek wisata SSS Silver maupun dekorasi ruangan, pelatakan dan layout galeri SSS Silver yang dapat menarik perhatian pelanggan. Proses (process) merupakan seluruh kegiatan yang dilakukan SSS Silver dalam menunjukkan bagaimana pelayanan diberikan kepada pelanggan selama melakukan aktivitas belanja. Kemasan (Packaging) adalah proses melampirkan atau melindungi produk untuk distribusi, penyimpanan, penjualan, dan penggunaan juga mengacu pada proses desain, evaluasi, dan produksi paket dan citra organisasi SSS Silver. Pembayaran (Payment) merupakan uang tunai, cek, atau kredit dalam ketentuan pembayaran untuk mempengaruhi kemudahan transaksi yang juga dapat mempengaruhi perilaku pembelian konsumen terhadap paket wisata SSS Silver.

Adapun indikator yang digunakan dalam penelitian ini akan dipaparkan dalam Tabel 4. yang selanjutnya seluruh indikator akan dikelompokan dalam analisis SWOT. Oleh sebab itu, Tabel 4. berikut merupakan rangkuman variable dan Indikator Persepsi Pelanggan dan manajemen pada SSS Silver.

Tabel 4.

Variabel dan Indikator Persepsi Pelanggan

\begin{tabular}{|c|c|c|c|}
\hline Faktor & Variabel & & Indikator \\
\hline \multirow{6}{*}{$\begin{array}{l}\text { Bauran } \\
\text { Pemasaran } \\
\text { (Marketing } \\
\text { mix) }\end{array}$} & $\begin{array}{l}\text { 1. Produk } \\
\text { (Product) }\end{array}$ & 1) & $\begin{array}{l}\text { Variasi produk yang ditawarkan } \\
\text { menarik }\end{array}$ \\
\hline & & 2) & $\begin{array}{l}\text { produk memenuhi kebutuhan } \\
\text { pelanggan }\end{array}$ \\
\hline & & 3) & Banyaknya pilihan varian perhiasan \\
\hline & $\begin{array}{l}2 . \quad \text { Harga } \\
\text { (Price) }\end{array}$ & 1) & $\begin{array}{l}\text { Harga pokok penjualan yang ditetapkan } \\
\text { terjangkau konsumen }\end{array}$ \\
\hline & & 2) & $\begin{array}{l}\text { Kesesuaian harga produk dengan } \\
\text { produk yang didapatkan konsumen }\end{array}$ \\
\hline & & 3) & $\begin{array}{l}\text { Persaingan harga yang mempengaruhi } \\
\text { daya beli }\end{array}$ \\
\hline
\end{tabular}

Bersambung... 


\begin{tabular}{|c|c|c|c|}
\hline \multirow[t]{2}{*}{ Faktor } & \multirow{2}{*}{$\begin{array}{l}\text { Variabel } \\
\text { 3. Distribusi } \\
\text { (Place) }\end{array}$} & \multicolumn{2}{|c|}{ Indikator } \\
\hline & & 1) & $\begin{array}{l}\text { Penyampaian informasi paket produk } \\
\text { jelas }\end{array}$ \\
\hline & & 2) & $\begin{array}{l}\text { Alamat kantor yang dapat dihubungi } \\
\text { lengkap }\end{array}$ \\
\hline & & 3) & $\begin{array}{l}\text { Pemasaran produk dengan mengikuti } \\
\text { pameran }\end{array}$ \\
\hline & 4. Promosi & 1) & Promosi yang dilakukan bermanfaat \\
\hline & (Promotion) & 2) & Intesitas promosi \\
\hline & 5. Personal & 1) & Kualitas pelayanan yang diberikan baik \\
\hline & (People) & 2) & Staff SSS Silver ramah \\
\hline & & 3) & Staff mampu menangani keluhan \\
\hline & & 4) & Kurangnya tenaga kerja \\
\hline & & 5) & $\begin{array}{l}\text { Karyawan mengalami kesulitan ketika } \\
\text { orderan meningkat }\end{array}$ \\
\hline & & 6) & Ketrampilan karyawan \\
\hline & $\begin{array}{l}\text { 6. Bukti Fisik } \\
\text { (Physical }\end{array}$ & 1) & $\begin{array}{l}\text { Fasilitas gerai toko SSS Silver dalam } \\
\text { kondisi baik }\end{array}$ \\
\hline & Evidance) & 2) & $\begin{array}{l}\text { Gerai toko SSS siver memberikan } \\
\text { kenyamanan saat pelanggan berbelanja }\end{array}$ \\
\hline & 7. Proses & 1) & Proses pemesanan lama \\
\hline & (Process) & 2) & $\begin{array}{l}\text { Proses produksi membutuhkan waktu } \\
\text { lama }\end{array}$ \\
\hline & & 3) & $\begin{array}{l}\text { Kesesuaian model yang ditawarkan } \\
\text { dengan produk yang tersedia }\end{array}$ \\
\hline & & 4) & $\begin{array}{l}\text { Tidak adanya hubungan bisnis dengan } \\
\text { pengusaha perak lain }\end{array}$ \\
\hline & $\begin{array}{l}\text { 8. Kemasan } \\
\text { (Packaging) }\end{array}$ & 1) & $\begin{array}{l}\text { Pengemasan paket produk SSS Silver } \\
\text { menarik }\end{array}$ \\
\hline & & 2) & $\begin{array}{l}\text { Mempunyai cirri khas Design produk } \\
\text { dengan saingan }\end{array}$ \\
\hline & 9.Pembayaran & 1) & Pembayaran produk SSS Silver mudah \\
\hline & (Payment) & 2) & $\begin{array}{l}\text { Pembayaran menggunakan Kemajuan } \\
\text { teknologi digital }\end{array}$ \\
\hline
\end{tabular}

Sumber: (Helms \& Nixon, 2010; Putong, 2003; Sudana, 2013; Suranta, 2015; Widiastuti, 2013)

Tujuan wawancara dan pemberian kuesioner dilakukan adalah untuk memperoleh informasi tambahan dan memperkuat pembahasan dalam penelitian ini terkait pemasaran produk yang sudah dilakukan oleh SSS Silver. Teknik analisis yang digunakan dalam penelitian ini adalah teknik deskriptif kualitatif yaitu analisis yang menguraikan, menggambarkan, dan menjelaskan secara sistematis data yang diperoleh dilapangan melalui wawancara dengan tujuan untuk memperoleh gambaran yang jelas dan objektif. Untuk mengetahui strategi pemasaran yang bisa diterapkan oleh SSS Silver akan digunakan analisis SWOT yaitu pendekatan deskriptif kualitatif terhadap suatu perusahaan yang menyangkut berbagai kekuatan (strengths), kelemahan (weakness), peluang (opportunities), dan ancaman (threats) terhadap suatu perusahaan.

\section{HASIL DAN PEMBAHASAN}


Kabupaten Gianyar yang memiliki industri kerajinan perak di empat kecamatan yaitu: Kecamatan Gianyar, Ubud, Sukawati dan Tampaksiring. Diantara empat Kecamatan tersebut Kecamatan Sukawati menjadi kecamatan yang terbesar dalam hal produksi kerajinan perak. Kecamatan Sukawati memiliki jumlah unit usaha paling banyak yaitu 117 usaha, kemudian kecamatan Ubud sebanyak 4 usaha, kecamatan Gianyar 2 usaha, dan kecamatan Tampak Siring hanya 1 usaha (Dinas Perindustrian dan Perdagangan Gianyar, 2018). Sehingga Kecamtan Suawati dikatakan sebagai sentra kerajina perak yang ada di kabupaten Gianyar. Dari 117 pengusaha kerajinan perak yang ada di kecamatan Sukawati tersebar di tujuh desa, yaitu: di desa Celuk sebanyak 33 pengusaha, desa Batubulan sebanyak 29 usaha, di desa Singapadu sebanyak 27 usaha, desa Sukawati sebanyak 10 usaha, desa singapadu Tengah sebanyak 7 usaha, desa Batuan 6 usaha, dan desa Kemenuh hanya 5 usaha. Dari tujuh desa yang ada kecamatan Sukawati, desa Celuk merupakan sentra maupun pelopor dari adanya kerajinan perak. Namun dengan adanya perkembangan pariwisata dan permintaan kerajinan perak yang semakin membaik, maka kerajinan dan bisnis perak menyebar ke desa lain. Dari tujuh desa yang ada di kecamatan Sukawati, desa Celuk tetap menjadi leader dari desa lainnya, namun ada desa lain yang perkembangan dapat menyaingi desa Celuk, yaitu desa Singapadu dan desa Batubulan. Sehingga Jalur yang melalui ketiga desa tersebut banyak beroprasi atau berdiri Gallery Gold \& Silver. Dengan adanya perkembangan teknologi informasi dan meningkatnya persaingan bisnis mas dan perakantar daerah dan antar negara, penjualan yang dicapai oleh pengusaha perak terutama penjualan yang sifatnya konvensional menurun dratis terutama yang dijual melalui gallery yang ada di sepanjang jalur Batubulan, Celuk dan Singapadu. Sehingga secara keseluruhan perkembangan bisnis perak yang ada di kabupaten Gianyar mengalami kelesuan yang sangat signifikan.

SSS Silver terinspirasi oleh almarhum Bapak kembar Kerepun, yang telah berada di Bali perak manik dan bisnis perhiasan sejak 1994. Pendiri dan pemilik Usaha SSS Silver adalah Bapak Nyoman Satyawibawa Upadhana. Nama Usaha SSS Silver diperoleh dari singkatan ketiga nama anak-anak Bapak Satyawibawa. Usaha SSS Silver tidak berhubungan dengan singkatan nama perusahaan lain. Usaha SSS Silver terletak di Celuk, pusat industri perhiasan emas dan perak di Bali. Usaha SSS Silver bukan produsen perhiasan perak Bali dengan ukuran perusahaan yang besar, tetapi Usaha SSS Silver menyediakan grosir, pengecer dan pembeli di seluruh dunia dengan tangan berkualitas perhiasan perak kerajinan.

Usaha SSS Silver mengkhususkan diri dalam produksi dan ekspor buatan perhiasan perak Bali termasuk: Rings, Earrings, Pendants, gelang, kalung, Hairclips, Bali Silver manik, ballpoints, set Jewelry dan produk baru SSS Silver adalah Beaded Jewelry. Usaha SSS Silver memproduksi dan menjual grosir biji perak Bali, kerucut, spacer, toggles, topi, gesper, temuan dan manik Indonesia lainnya. Semua produk Usaha SSS Silver terbuat dari 925 Sterling Silver dan dibuat secara individual oleh pengrajin perak yang sangat terampil di Bali, Indonesia. Usaha SSS Silver menawarkan perak Bali yang unik. Desain pada masing-masing bagian perak yang dijual oleh SSS Silver mewakili sebuah karya 
seni dengan kualitas yang luar biasa dan dikerjakan dengan detail. SSS Silver saat ini melakukan semua transaksi melalui email. Usaha SSS Silver akan mengirimkan pesanan konsumen dalam 1 hari pembayaran (untuk pembelian stok barang) dan akan tiba di alamat pengiriman konsumen sekitar 4 hari setelah tanggal pengiriman (jika tidak ada keterlambatan pabean)

Deskripsi data persepsi responden terhadap indikator indikator bauran pemasaran pada SSS Silver di Bali, yang terdiri dari: produk (product), Harga (Price), Distribusi (Place), Promosi (Promotion), Personal (People), Bukti Fisik (Physical Evidance), Proses (Process), Kemasan (Packaging) dan Pembayaran (Payment) diperoleh melalui penyebaran kuisioner. Variabel bauran pemasaran dalam penelitian ini merupakan variabel yang diukur dengan menggunakan 16 pertanyaan yang berhubungan dengan bauran pemasaran pada SSS Silver di Bali. Secara rinci hasil penelitian mengenai persepsi responden disajikan pada Tabel 5.

Tabel 5.

Deskripsi Pada Faktor Internal

\begin{tabular}{|c|c|c|c|c|c|c|c|c|}
\hline \multirow{2}{*}{ No } & \multirow{2}{*}{ Pertanyaan } & \multicolumn{5}{|c|}{ Proporsi Persepsi Responden (\%) } & \multirow{2}{*}{$\begin{array}{l}\text { Rata- } \\
\text { Rata }\end{array}$} & \multirow{2}{*}{ Kriteria } \\
\hline & & 1 & 2 & 3 & 4 & 5 & & \\
\hline 1 & $\begin{array}{l}\text { Harga pokok penjualan yang } \\
\text { ditetapkan terjangkau } \\
\text { konsumen }\end{array}$ & 0 & 0 & 2 & 1 & 0 & 3,33 & Cukup \\
\hline 2 & $\begin{array}{l}\text { Produk memenuhi kebutuhan } \\
\text { pelanggan }\end{array}$ & 0 & 0 & 1 & 2 & 0 & 3,67 & Baik \\
\hline 3 & $\begin{array}{l}\text { Kesesuaian harga produk } \\
\text { dengan produk yang } \\
\text { didapatkan konsumen }\end{array}$ & 0 & 0 & 0 & 3 & 0 & 4,00 & Baik \\
\hline 4 & $\begin{array}{l}\text { Variasi produk yang } \\
\text { ditawarkan menarik }\end{array}$ & 0 & 0 & 0 & 2 & 1 & 4,33 & Baik \\
\hline 5 & $\begin{array}{l}\text { Kualitas pelayanan yang } \\
\text { diberikan baik }\end{array}$ & 0 & 0 & 1 & 2 & 0 & 3,67 & Baik \\
\hline 6 & $\begin{array}{l}\text { Banyaknya pilihan varian } \\
\text { perhiasan }\end{array}$ & 0 & 0 & 2 & 1 & 0 & 3,33 & Cukup \\
\hline 7 & $\begin{array}{l}\text { Kualitas pelayanan yang } \\
\text { diberikan baik }\end{array}$ & 0 & 0 & 0 & 3 & 0 & 4,00 & Baik \\
\hline 8 & Staff SSS Silver ramah & 0 & 0 & 0 & 3 & 0 & 4,00 & Baik \\
\hline 9 & $\begin{array}{l}\text { Staff mampu menangani } \\
\text { keluhan }\end{array}$ & 0 & 0 & 2 & 1 & 0 & 3,33 & Cukup \\
\hline 10 & $\begin{array}{l}\text { Promosi yang dilakukan } \\
\text { selalu menarik perhatian }\end{array}$ & 0 & 0 & 1 & 2 & 0 & 3,67 & Baik \\
\hline 11 & $\begin{array}{l}\text { Fasilitas gerai toko SSS } \\
\text { Silver dalam kondisi baik }\end{array}$ & 0 & 0 & 1 & 2 & 0 & 3,67 & Baik \\
\hline 12 & Intesitas promosi & 0 & 0 & 1 & 2 & 0 & 3,67 & Baik \\
\hline 13 & $\begin{array}{l}\text { Gerai toko SSS Silver } \\
\text { memberikan kenyamanan } \\
\text { saat pelanggan berbelanja }\end{array}$ & 0 & 0 & 0 & 3 & 0 & 4,00 & Baik \\
\hline 14 & $\begin{array}{l}\text { Pembayaran produk SSS } \\
\text { Silver mudah }\end{array}$ & 0 & 0 & 0 & 3 & 0 & 4,00 & Baik \\
\hline \multicolumn{7}{|c|}{ Rata-Rata Skor Faktor Internal kekuatan } & 3,76 & Baik \\
\hline
\end{tabular}


Lanjutan Tabel 5.

\begin{tabular}{|c|c|c|c|c|c|c|c|c|}
\hline \multirow{2}{*}{ No } & \multirow{2}{*}{ Pertanyaan } & \multicolumn{5}{|c|}{ Proporsi Persepsi Responden (\%) } & \multirow{2}{*}{$\begin{array}{l}\text { Rata- } \\
\text { Rata }\end{array}$} & \multirow{2}{*}{ Kriteria } \\
\hline & & 1 & 2 & 3 & 4 & 5 & & \\
\hline 1 & $\begin{array}{l}\text { Kurangnya tenaga kerja } \\
\text { Karyawan mengalami }\end{array}$ & 0 & 0 & 2 & 1 & 0 & 3,33 & Cukup \\
\hline 2 & $\begin{array}{l}\text { kesulitan ketika orderan } \\
\text { meningkat }\end{array}$ & 0 & 0 & 2 & 1 & 0 & 3,33 & Cukup \\
\hline 3 & Ketrampilan karyawan & 0 & 0 & 0 & 3 & 0 & 4,00 & Baik \\
\hline 4 & $\begin{array}{l}\text { Proses produksinya } \\
\text { membutuhkan waktu lama }\end{array}$ & 0 & 0 & 1 & 2 & 0 & 3,67 & Baik \\
\hline 5 & $\begin{array}{l}\text { Kesesuaian model yang } \\
\text { ditawarkan dengan produk } \\
\text { yang tersedia }\end{array}$ & 0 & 0 & 0 & 3 & 0 & 4,00 & Baik \\
\hline 6 & Proses pemesanan lama & 0 & 0 & 2 & 1 & 0 & 3,33 & Cukup \\
\hline \multicolumn{7}{|c|}{ Rata-Rata Skor Faktor Internal kelemahan } & 3,61 & Baik \\
\hline \multicolumn{7}{|c|}{ Rata-rata keseluruhan persepsi responden pada Faktor Internal } & 3,67 & Baik \\
\hline
\end{tabular}

Sumber : Data primer diolah, 2020

Tabel 5. menunjukkan pertanyaan-pertanyaan yang diajukan yang berkaitan dengan bauran pemasaran oleh SSS Silver di Bali khususnya pada faktor internal. Apabila ditinjau berdasarkan rata-rata skor faktor internal, data menunjukkan nilai rata-rata faktor internal kekuatan sebesar 3,74, sedangkan rata-rata faktor internal kelemahan sebesar 3,61. Hal ini memberikan makna bahwa SSS Silver memiliki faktor internal kekuatan yang lebih besar dibandingkan faktor internal kelemahan.

Perolehan nilai tertinggi terdapat pada pertanyaan "Variasi produk yang ditawarkan menarik" dengan rata-rata 3,76, memiliki arti bahwa secara keseluruhan variasi produk yang ditawarkan oleh SSS Silver dibuat agar dapat menarik perhatian pelanggannya. Persepsi responden dengan nilai rata-rata terendah terdapat pada pernyataan, "Harga pokok penjualan yang ditetapkan terjangkau konsumen", "Banyaknya pilihan varian perhiasan", dan "Staff mampu menangani keluhan", dengan nilai sebesar 3,33. Hal ini berarti bahwa menurut responden yaitu pihak manajemen SSS Silver yaitu masih kurang banyak piihan varian perhiasan yang ditawarkan SSS Silver, kemudian harga pokok penjualan cenderung mahal, sehingga tidak semua konsumen dapat menjangkau harga jual tersebut. Selain itu, staff SSS Silver masih kurang mampu menangani keluhan pelanggan secara cepat tanggap. Faktor internal yang memperoleh nilai rata-rata terendah adalah indikator "kurangnya tenanga kerja", dan karyawan mengalami kesulitan ketika orderan meningkat" yakni dengan nilai rata-rata sebesar 3,33. Hal ini berarti bahwa menurut responden yaitu pihak manajemen SSS Silver yaitu usaha SSS Silver masih kurang memiliki tenaga kerja dan masih ada karyawan yang mengalami kesulitan ketika pesanan meningkat.

Struktur organisasi SSS Silver terdiri dari 1) Director, bertugas menjalankan Usaha SSS Silver untuk mengarahkan kegiatan-kegiatan sehari-hari berdasarkan kebijaksanaan yang telah ditetapkan serta bertanggung jawab atas pelaksanaan operasi perusahaan secara penuh baik keluar maupun ke dalam perusahaan. 2)

Sales \& Marketing Manager, bertanggung jawab untuk menangani tugastugas manajemen yang telah dirumuskan dan diarahkan oleh Director, 
dilaksanakan dan dikomunikasikan kepada bagian operasional bagian keuangan dan diteruskan kepada masing-masing staf produks dan pengrajin. 3) Bagian Operasional, bertanggung jawab dalam hal perencanaan, pengendalian, pelaksanaan dan pengawasan operasional Usaha SSS Silver. Termasuk pengembangan kualitasnya dengan berpedoman pada kebijakan dan prosedur yang berlaku di perusahaan, serta bertanggung jawab terhadap hal-hal yang berkaitan dengan kegiatan pembinaan pemerintah dan industrial serta mempunyai kewajiban memelihara dan menjaga citra perusahaan. 4) Finance, bertugas untuk mengkalkulasikan seluruh keuangan (sumber dan penggunaannya) dan bertanggung jawab melaporkan kepada Director. 5) Staf Produksi dan pengrajin, memiliki tugas untuk melakukan produksi kerajinan perak pada Usaha SSS Silver secara teliti dan hati-hati, serta bertanggungjawab untuk menghasilkan produk kerajinan perak yang berkualitas dan sesuai pesanan pelanggan.

Rata-rata keseluruhan persepsi responden memperoleh hasil yang tinggi yakni sebesar 3,67. Hal ini menunjukan indikator dalam penyataan tersebut menjawab bahwa konsumen sudah merasakan kualitas produk (product), Harga (Price), Distribusi (Place), Promosi (Promotion), Personal (People), Bukti Fisik (Physical Evidance), Proses (Process), Kemasan (Packaging) dan Pembayaran (Payment) oleh SSS Silver di Bali yang baik.

Tabel 6.

Deskripsi Persepsi Responden Pada Faktor Eksternal

\begin{tabular}{|c|c|c|c|c|c|c|c|c|}
\hline \multirow{2}{*}{ No } & \multirow{2}{*}{ Pertanyaan } & \multicolumn{5}{|c|}{ Proporsi Persepsi Responden (\%) } & \multirow{2}{*}{$\begin{array}{l}\text { Rata- } \\
\text { Rata }\end{array}$} & \multirow{2}{*}{ Kriteria } \\
\hline & & 1 & 2 & 3 & 4 & 5 & & \\
\hline 1 & $\begin{array}{l}\text { Penyampaian informasi paket } \\
\text { produk jelas }\end{array}$ & 0 & 0 & 0 & 3 & 0 & 4,00 & Baik \\
\hline 2 & $\begin{array}{l}\text { Alamat kantor yang dapat } \\
\text { dihubungi lengkap }\end{array}$ & 0 & 0 & 0 & 2 & 1 & 4,33 & Baik \\
\hline 3 & $\begin{array}{l}\text { Pemasaran produk dengan } \\
\text { mengikuti pameran }\end{array}$ & 0 & 0 & 1 & 2 & 0 & 3,67 & Baik \\
\hline 4 & $\begin{array}{l}\text { Mempunyai cirri khas Design } \\
\text { produk dengan saingan }\end{array}$ & 0 & 0 & 1 & 1 & 1 & 4,00 & Baik \\
\hline 5 & $\begin{array}{l}\text { Pengemasan paket produk } \\
\text { SSS Silver menarik }\end{array}$ & 0 & 0 & 2 & 1 & 0 & 3,33 & Cukup \\
\hline 6 & $\begin{array}{l}\text { Gaya hidup atau selera } \\
\text { konsumen }\end{array}$ & 0 & 0 & 1 & 2 & 0 & 3,67 & Baik \\
\hline 7 & $\begin{array}{l}\text { Pembayaran mengikuti } \\
\text { kemajuan teknologi digital }\end{array}$ & 0 & 0 & 0 & 3 & 0 & 4,00 & Baik \\
\hline \multicolumn{7}{|c|}{ Rata-Rata Skor Faktor Eksternal Peluang } & 3,86 & Baik \\
\hline 1 & $\begin{array}{l}\text { Persaingan harga } \\
\text { mempengaruhi daya beli }\end{array}$ & 0 & 0 & 0 & 2 & 1 & 4,33 & Baik \\
\hline 2 & $\begin{array}{l}\text { Krisis ekonomi global } \\
\text { mempengaruhi daya beli }\end{array}$ & 0 & 0 & 2 & 1 & 0 & 3,33 & Cukup \\
\hline
\end{tabular}

Bersambung... 
Lanjutan Tabel 6.

\begin{tabular}{|c|c|c|c|c|c|c|c|c|}
\hline \multirow{2}{*}{ No } & \multirow{2}{*}{ Pertanyaan } & \multicolumn{5}{|c|}{ Proporsi Persepsi Responden (\%) } & \multirow{2}{*}{$\begin{array}{l}\text { Rata- } \\
\text { Rata }\end{array}$} & \multirow{2}{*}{ Kriteria } \\
\hline & & 1 & 2 & 3 & 4 & 5 & & \\
\hline 3 & $\begin{array}{l}\text { Tidak adanya hubungan } \\
\text { bisnis dengan pengusaha } \\
\text { perak lain }\end{array}$ & 0 & 0 & 1 & 2 & 0 & 3,67 & Baik \\
\hline \multicolumn{7}{|c|}{ Rata-Rata Skor Faktor Eksternal Ancaman } & 3,78 & Baik \\
\hline \multicolumn{7}{|c|}{ Rata-rata keseluruhan persepsi responden pada Faktor Eksternal } & 3,75 & Baik \\
\hline
\end{tabular}

Tabel 6. menunjukkan pertanyaan-pertanyaan yang diajukan yang berkaitan dengan bauran pemasaran oleh SSS Silver di Bali khususnya pada faktor eksternal. Apabila ditinjau berdasarkan rata-rata skor faktor eksternal, data menunjukkan nilai rata-rata faktor eksternal peluang sebesar 3,71, sedangkan ratarata faktor eksternal ancaman sebesar 3,78. Hal ini memberikan makna bahwa SSS Silver memiliki faktor eksternal peluang yang lebih besar dibandingkan faktor eksternal ancaman.

Perolehan nilai tertinggi terdapat pada pertanyaan "Alamat kantor yang dapat dihubungi lengkap" dengan rata-rata 4,33, memiliki arti bahwa secara keseluruhan pelanggan mudah menghubungi SSS Silver karena memiliki alamat kantor yang jelas dan dapat dihubungi karena memberikan nomor telepon serta alamat email yang lengkap pada website SSS Silver. Persepsi responden dengan nilai rata-rata terendah terdapat pada pernyataan, "Krisis ekonomi global mempengaruhi daya beli", dengan nilai sebesar 3,33. Hal ini berarti bahwa menurut pelanggan faktor krisis ekonomi global sangat berdampak pada tingkat pembelian konsumen pada produk kerajinan perak khususnya di SSS Silver. Kondisi ini sesuai dengan keadaan di lapangan yang menunjukkan sebagian besar masyarakat saat ini sedang mengalami krisis ekonomi global akibat adanya pandemi covid-19, sehingga membuat daya beli masyarakat pada produk kerajinan perak semakin menurun.

Pengembangan potensi Usaha SSS Silver dapat dilakukan dengan mengetahui dan memahami apa saja faktor internal dan eksternal yang digambarkan melalui matrik SWOT. Adapun matrik IFAS dapat dilihat pada Tabel 7. berikut.

Tabel 7.

Matrik IFAS (Internal Factory Analysis Summary)

\begin{tabular}{clccc}
\hline No & \multicolumn{1}{c}{ Faktor Strategi Internal } & Bobot & Rating & $\begin{array}{c}\text { Bobot x } \\
\text { Rating }\end{array}$ \\
\hline 1 & Harga pokok penjualan yang ditetapkan terjangkau konsumen & 0,05 & 3,33 & 0,167 \\
2 & Produk memenuhi kebutuhan pelanggan & 0,05 & 3,67 & 0,183 \\
3 & Kesesuaian harga produk dengan produk yang didapatkan & 0,05 & 4,00 & 0,200 \\
4 & konsumen & 0,05 & 4,33 & 0,217 \\
5 & Variasi produk yang ditawarkan menarik & 0,05 & 3,67 & 0,183 \\
6 & Kualitas pelayanan yang diberikan baik & 0,05 & 3,33 & 0,167 \\
7 & Kanyaknya pilihan varian perhiasan & 0,05 & 4,00 & 0,200 \\
\hline \multicolumn{2}{c}{ Bersambung... } & & &
\end{tabular}


Lanjutan Tabel 7.

\begin{tabular}{clccc}
\hline No & Faktor Strategi Internal & Bobot & $\begin{array}{c}\text { Ratin } \\
\text { g }\end{array}$ & $\begin{array}{c}\text { Bobot x } \\
\text { Rating }\end{array}$ \\
\hline 8 & Staff SSS Silver ramah & 0,05 & 4,00 & 0,200 \\
9 & Staff mampu menangani keluhan & 0,05 & 3,33 & 0,167 \\
10 & Promosi yang dilakukan selalu menarik perhatian & 0,05 & 3,67 & 0,183 \\
11 & Fasilitas gerai toko SSS Silver dalam kondisi baik & 0,05 & 3,67 & 0,183 \\
12 & Intesitas promosi & 0,05 & 3,67 & 0,183 \\
13 & Gerai toko SSS Silver memberikan kenyamanan saat & 0,05 & 4,00 & 0,200 \\
14 & pelanggan berbelanja & 0,05 & 4,00 & 0,200 \\
\hline Sub Total Faktor Kekuatan & $\mathbf{0 , 7}$ & & $\mathbf{2 , 6 3 3}$ \\
\hline 1 & Kurangnya tenaga kerja & 0,05 & 3,33 & 0,167 \\
2 & Karyawan mengalami kesulitan ketika orderan meningkat & 0,05 & 3,33 & 0,167 \\
3 & Ketrampilan karyawan & 0,05 & 4,00 & 0,200 \\
4 & Proses produksinya membutuhkan waktu lama & 0,05 & 3,67 & 0,183 \\
5 & Kesesuaian model yang ditawarkan dengan produk tersedia & 0,05 & 4,00 & 0,200 \\
6 & Proses pemesanan lama & 0,05 & 3,33 & 0,167 \\
\hline Sub Total Faktor kelemahan & 0,3 & & 1,083 \\
\hline Total Faktor Internal & 1,000 & 3,69 & 3,717 \\
\hline
\end{tabular}

Sumber: Data primer diolah, 2020

Strategi pengembangan SSS Silver harus didukung dengan adanya programprogram pengembangan yang efektif sehingga mampu memberikan dampak yang positif kepada pelanggan secara berkelanjutan. Analisis SWOT pada penelitian ini dilakukan dengan melakukan analisis internal dan eksternal yakni dengan membuat matrik IFAS (Internal Factory Analysis Summary) dan matrik EFAS (Eksternal Factory Analysis Summary).

Setelah mengetahui hasil nilai dari matrik IFAS dan matrik EFAS, maka dapat diposisikan pada perusahaan terkait hasil nilai dari matrik IFAS dan nilai dari matrik EFAS pada analisis SWOT. Berdasarkan hasil perhitungan matrik IFAS (Internal Factory Analysis Summary) pada Tabel 5. diketahui bahwa nilai kekuatan lebih tinggi dari nilai kelemahan yaitu sebesar $(+)$ 1,550. Selanjutnya matrik EFAS (Eksternal Factory Analysis Summary) dapat dilihat pada Tabel 6 berikut:

Tabel 8.

Matrik EFAS (Eksternal Factory Analysis Summary)

\begin{tabular}{clccc}
\hline No & \multicolumn{1}{c}{ Faktor Strategi Eksternal } & Bobot & Rating & $\begin{array}{c}\text { Bobot } \mathbf{x} \\
\text { Rating }\end{array}$ \\
\hline 1 & Penyampaian informasi paket produk jelas & 0,10 & 4,00 & 0,400 \\
2 & Alamat kantor yang dapat dihubungi lengkap & 0,10 & 4,33 & 0,433 \\
3 & Pemasaran produk dengan mengikuti pameran & 0,10 & 3,67 & 0,367 \\
4 & Mempunyai cirri khas Design produk dengan saingan & 0,10 & 4,00 & 0,400 \\
5 & Pengemasan paket produk SSS Silver menarik & 0,10 & 3,33 & 0,333 \\
6 & Gaya hidup atau selera konsumen & 0,10 & 3,67 & 0,367 \\
7 & Pembayaran mengikuti kemajuan teknologi digital & 0,10 & 4,00 & 0,400 \\
\hline Sub Total Faktor Eksternal Peluang & $\mathbf{0 , 7 0}$ & & $\mathbf{2 , 7 0 0}$ \\
\hline 1 & Persaingan harga mempengaruhi daya beli & 0,10 & 4,33 & 0,433 \\
\hline Bersambung... & & &
\end{tabular}


Lanjutan Tabel 8.

\begin{tabular}{clccc}
\hline No & Faktor Strategi Eksternal & $\begin{array}{c}\text { Bobo } \\
\mathbf{t}\end{array}$ & $\begin{array}{c}\text { Ratin } \\
\text { g }\end{array}$ & $\begin{array}{c}\text { Bobot x } \\
\text { Rating }\end{array}$ \\
\hline 2 & Krisis ekonomi global mempengaruhi daya beli & 0,10 & 3,33 & 0,333 \\
3 & Tidak adanya hubungan bisnis dengan pengusaha perak lain & 0,10 & 3,67 & 0,367 \\
\hline Sub Total Faktor Eksternal Ancaman & 0,30 & 1,133 \\
\hline Total Faktor Eksternal & 1,00 & 3,67 & 3,833 \\
\hline Sumber: Data primer diolah, 2020 & &
\end{tabular}

Berdasarkan hasil perhitungan matrik EFAS (Eksternal Factory Analysis Summary) pada Tabel 8. diketahui bahwa nilai faktor eksternal peluang lebih tinggi dari nilai faktor ancaman yaitu sebesar $(+)$ 1,567. Berdasarkan pada matriks IFAS dan EFAS, maka dapat ditentukan diagram SWOT berikut ini:

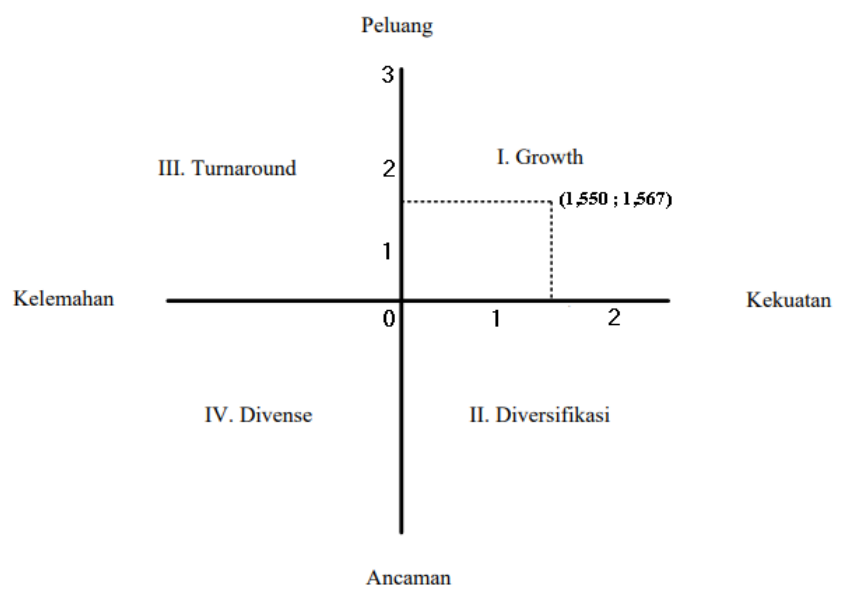

Sumber: Data diolah, 2020

\section{Gambar 1. Diagram Matriks SWOT}

Gambar 1. menunjukkan bahwasannya Usaha SSS Silver berada dalam jalur yang melakukan stategi pengembangan (growth) hal ini dapat dilihat pada Usaha SSS Silver tersebut meningkatkan keunggulan produk serta mempertahankan penjualan produk dengan pelanggannya, maka dapat ditentukan strategi yang tepat untuk mengembangkan pemasaran SSS Silver di Bali dengan menggunakan analisis SWOT pada Tabel 7.

Berdasarkan hasil matriks SWOT pada Tabel 9., maka dapat diketahui bahwa kekuatan yang dimiliki Usaha SSS Silver untuk mengembangkan usaha ini tergolong cukup kuat dan memiliki peluang yang sangat baik untuk tetap mengembangkan usaha ini. Namun terdapat beberapa ancaman dan kelemahan yang perlu mendapat perhatian khusus dari pihak manajemen untuk dapat mengembangkan Usaha SSS Silver dengan beberapa strategi.

Hasil menunjukkan bahwa Usaha SSS Silver memiliki banyak kekuatan begitu pun dengan peluang yang ada untuk terus mengembangkan usaha ini. Dengan demikian perusahaan ini hanya perlu meningkatkan kekuatan yang diperoleh untuk menanggapi setiap peluang yang tercipta. 


\section{Tabel 9.}

\section{Matrik SWOT Strategi Pemasaran SSS Silver di Bali}

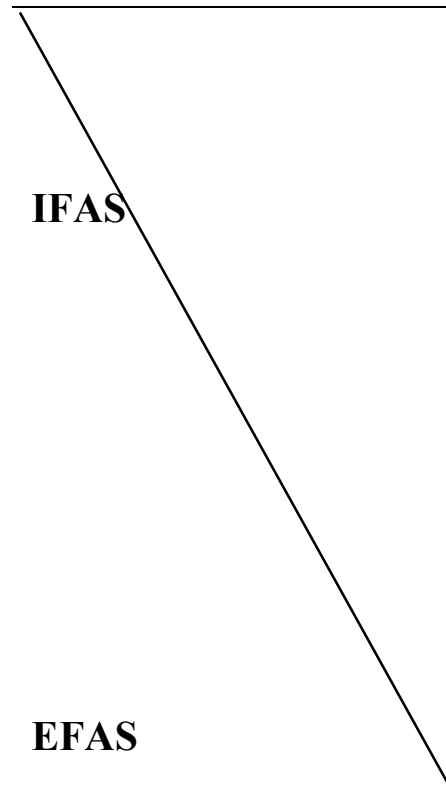

Strenghts (Kekuatan)

1) Harga pokok penjualan yang ditetapkan terjangkau konsumen

2) Produk memenuhi kebutuhan pelanggan

3) Kesesuaian harga produk dengan produk yang didapatkan konsumen

4) Variasi produk yang ditawarkan menarik

5) Kualitas pelayanan yang diberikan baik

6) Banyaknya pilihan varian perhiasan

7) Kualitas pelayanan yang diberikan baik

8) Staff SSS Silver ramah

9) Staff mampu menangani keluhan

10) Promosi yang dilakukan selalu menarik perhatian

11) Fasilitas gerai toko SSS Silver dalam kondisi baik

12) Intesitas promosi

13) Gerai toko SSS Silver

memberikan kenyamanan saat pelanggan berbelanja

14) Pembayaran produk SSS Silver mudah
Weakness (Kelemahan)

1) Kurangnya tenaga kerja

2) Karyawan mengalami kesulitan ketika orderan meningkat

3) Ketrampilan karyawan

4) Proses produksinya membutuhkan waktu lama

5) Kesesuaian model yang ditawarkan dengan produk yang tersedia

6) Proses pemesanan lama
1) Ppportunities (Peluang) paket produk jelas

2) Alamat kantor yang dapat dihubungi lengkap

3) Pemasaran produk dengan mengikuti pameran

4) Mempunyai cirri khas Design produk dengan saingan

5) Pengemasan paket produk SSS Silver menarik

6) Gaya hidup atau selera konsumen

7) Pembayaran mengikuti kemajuan teknologi digital

Threats (Ancaman)

1) Persaingan harga mempengaruhi daya beli

2) Krisis ekonomi global mempengaruhi daya beli

3) Tidak adanya hubungan bisnis dengan pengusaha perak lain

\section{STRATEGI (SO)}

1) Meningkatkan keunggulan produk seperti meningkatkan kualitas bahan baku perak yang digunakan dan melakukan inovasi lebih bervariasi.

2) Mengikuti event-event yang ada untuk memperkenalkan hasil kerajinan perak SSS Silver.

3) Meningkatkan kerjasama dengan konsumen atau pengrajin untuk mengembangkan usaha kerajinan perak SSS Silver.

4) Memanfaatkan teknologi yang modern sebagai media promosi produk kerajinan perak pada usaha SSS Silver

\section{STRATEGI (ST)}

1) Meningkatkan kualitas produk

2) Mempertahankan harga yang relatif murah dibanding dengan pesaing lainnya.

3) Meningkatkan kerjasama terhadap paguyuban dan pemerintah serta pengepul.

4) Membuat produk dalam skala besar agar dapat hemat biaya produksi yang dibutuhkan.
STRATEGI (WO)

1) Membuat website dan jejaring yang lain sebagai media promosi.

2) Mencari kerja sama atau mitra bisnis agar dapat mengembangkan usaha.

3) Menggunakan alat yang lebih modern.

4) Lebih memperluas jaringan promosi iklan ke seluruh indonesia sebagai usaha mencapai tujuan.

5) Mencari dukungan dari pemerintah agar lebih memerhatikan indutri kerajinan, dan mengaktifkan kembali paguyuban yang sudah ada.

STRATEGI (WT)

1) Melakukan pelatihan ketrampilan untuk meningkatkan tenaga kerja.

2) Melakukan penyetokan bahan baku agar mengurangi biaya transportasi.

3) Mencari relasi dengan pihak-pihak terkait seperti pemerintahan agar mengenalkan produk dengan negara lain.

4) Mencari pinjaman dana atau menjalin kerjasama dengan investor 
Meningkatkan keunggulan produk seperti meningkatkan kualitas bahan baku perak yang digunakan dan melakukan inovasi lebih bervariasi. Mengikuti event-event yang ada untuk memperkenalkan hasil kerajinan perak SSS Silver. Meningkatkan kerjasama dengan konsumen atau pengrajin untuk mengembangkan usaha kerajinan perak SSS Silver. Memanfaatkan teknologi yang modern sebagai media promosi produk kerajinan perak pada usaha SSS Silver. Selain memiliki banyak kekuatan, terdapat juga beberapa kelemahan yang perlu diperhatikan dengan cara meminimalisir kelemahan tersebut atau lebih meningkatkan kekuatan yang yang telah dimiliki. Membuat website dan jejaring yang lain sebagai media promosi. Mencari kerja sama atau mitra bisnis agar dapat mengembangkan usaha. Menggunakan alat yang lebih modern. Lebih memperluas jaringan promosi iklan ke seluruh indonesia sebagai usaha mencapai tujuan. Mencari dukungan dari pemerintah agar lebih memerhatikan indutri kerajinan, dan mengaktifkan kembali paguyuban yang sudah ada.

Posisi saat ini dapat dipertahankan dengan meninjau ancaman yang ada maka pihak pemerintah serta stakeholder harus bekerjasama dan meningkatkan kekuatan masing-masing terhadap ancaman-ancaman tersebut. Meningkatkan kualitas produk. Mempertahankan harga yang relatif murah dibanding dengan pesaing lainnya. Meningkatkan kerjasama terhadap paguyuban dan pemerintah serta pengepul. Membuat produk dalam skala besar agar dapat hemat biaya produksi yang dibutuhkan.

Upaya yang dapat dilakukan untuk mengurangi kelemahan dan ancaman yang ada, maka diperlukan beberapa strategi dalam mengatasi kelemahan yang dimiliki dan merubahnya menjadi suatu kekuatan baru untuk tetap berkembang dari suatu ancaman. Melakukan pelatihan ketrampilan untuk meningkatkan tenaga kerja. Melakukan penyetokan bahan baku agar mengurangi biaya transportasi. Mencari relasi dengan pihak-pihak terkait seperti pemerintahan agar mengenalkan produk dengan negara lain. Mencari pinjaman dana atau menjalin kerjasama dengan investor.

\section{SIMPULAN}

Berdasarkan hasil analisis maka dapat disimpulkan bahwa Faktor internal dominan yang mempengaruhi usaha kerajinan perak SSS Silver dalam menjalankan operasional perusahaannya adalah faktor kekuatan, sedangkan faktor eksternal yang dominan adalah faktor peluang usaha yang dimiliki SSS Silver. Hasil dari penelitian pada tabel IFAS (Internal Strategic Factor Analysis Summary) skor pembobotannya adalah 3,717 dan untuk tabel EFAS (Enternal Strategic Factor Analysis Summary) skor pembobotannya adalah 3,833. Berdasarkan dari hasil analisis faktor internal dan faktor eksternal industri beserta diagram SWOT didapat bahwa yang menjadi strategi utama dalam industri kerajinan perak pada usaha SSS Silver adalah strategi growth (perkembangan), dimana pada industri kerajinan perak pada usaha SSS Silver dapat meningkatkan keunggulan produk, kualitas yang dimiliki dan pemanfaatan promosi denga media teknologi yang berkembang yang lebih baik. 
Berdasarkan hasil analisis SWOT, maka strategi yang tepat digunakan oleh usaha kerajinan perak SSS Silver adalah model strategi SO yaitu strategi yang menggunakan kekuatan (Strength) dan dengan memanfaatkan peluang (Opportunies) yang dimiliki pada industri yaitu dalam meningkatkan keunggulan produk seperti meningkatkan kualitas bahan baku perak yang digunakan dan melakukan inovasi lebih bervariasi, kemudian mengikuti event-event yang ada untuk memperkenalkan hasil produk kerajinan perak pada usaha SSS Silver, lalu meningkatkan kerjasama dengan konsumen atau pengarajin untuk mengembangkan usaha, serta memanfaatkan teknologi yang modern sebagai media promosi produk kerajinan perak pada usaha SSS Silver.

Pihak Usaha SSS Silver diharapkan mampu untuk meningkatkan kekuatannya, serta mampu untuk mengatasi kelemahan yang dimiliki. Usaha SSS Silver juga harus mampu melihat dengan baik peluang-peluang yang ada dan mampu memaksimalkan peluang tersebut demi mencapai visi, misi, dan tujuannya. Usaha SSS Silver harus mampu mengatasi setiap ancaman dan permasalahan yang muncul, sehingga dengan antisipasi dan penanganan yang tepat dapat meminimalisir dampak dari ancaman tersebut.

Adapun usulan pengembangan strategi yang dapat diberikan pada usaha kerajinan perak SSS Silver yaitu Usaha SSS Silver sebaiknya meningkatkan keunggulan produk kerajinan perak yang dimiliki dan mempertahankan dari segi seninya serta kekuatan industri kerajinan perak tersebut dan memperdalam lagi dari segi seninya agar para penggemar kerajinan perak lebih mencari kerajinan perak yang unik dengan jiwa seni yang tinggi. Kemudian, menjaga pelayanan yang sebaik mungkin dengan pelanggan atau pun dengan pengrajin perak yang ada di Gianyar maupun Bali. Selain itu, SSS Silver sebaiknya memanfaatkan media teknologi sebagai promosi serta untuk memperluas jaringan pemasaran diseluruh Indonesia maupun dinegara-negara lain. Lalu mengikuti pameranpameran yang sudah disiapkan dari pemerintah yaitu yang menaungi dari dinas perindustrian sebagai peningkatan pemasaran dan memperkenalkan hasil karya kerajinan perak pada usaha SSS Silver.

Pengrajin pada SSS Silver harus dapat mengaktifkan paguyuban kerajinan perak agar tidak terjadi pesaingan dengan pengrajin yang lain, dan dengan dibentuknya paguyuban ini dapat menampung keluhan-keluhan yang pengrajin alami serta dapat menjadi media sebagai pemasaran produk kerajinan perak.

\section{REFERENSI}

Amelia, M. N., Prasetyo, Y. E., \& Maharani, I. (2017). E-Umkm: Aplikasi Pemasaran Produk Umkm Berbasis Android Sebagai Strategi Meningkatkan Perekonomian Indonesia. Prosiding SNATIF Ke-4.

Dwi, A. H. (2011). Analisis Pengaruh Kualitas Produk, Persepsi Harga, Dan Kualitas Layanan Terhadap Minat Beli Ulang Produk Perlengkapan Kunci Di Pt Kenari Djaja Prima Semarang. Jurnal Sains Pemasaran Indonesia, 10(1), 47-87. https://doi.org/10.14710/jspi.v10i1.47 
Ghazinoory, S., Abdi, M., \& Azadegan-Mehr, M. (2011). Swot methodology: A state-of-the-art review for the past, a framework for the future. Journal of Business Economics and Management. https://doi.org/10.3846/16111699.2011.555358

Helms, M. M., \& Nixon, J. (2010). Exploring SWOT analysis - where are we now?: A review of academic research from the last decade. Journal of Strategy and Management. https://doi.org/10.1108/17554251011064837

Hoiron, M., Wahyudi, E., \& Puspitaningtyas, Z. (2019). Pengaruh Kapabilitas Pemasaran, Keunggulan Bersaing Dan Budaya Organisasi Terhadap Kinerja Ukm (Usaha Kecil Dan Menengah) Di Kabupaten Lumajang. Majalah Ilmiah DIAN ILMU, 18(1), 37-53. https://doi.org/10.37849/midi.v18i1.108

Kurniansah, R., \& Rosida, L. (2019). Strategi Pengembangan Pariwisata Perkotaan (Urban Tourism) Kota Mataram Provinsi Nusa Tenggara Barat. Media Bina Ilmiah. https://doi.org/10.33758/mbi.v14i2.304

Lestari, K. J., \& Wirathi, I. G. A. P. (2016). Pengaruh Jumlah Produksi, Tenaga Kerja Dan Kurs Valuta Asing Terhadap Ekspor Perhiasan Perak Di Kabupaten Gianyar. E-Jurnal Ekonomi Pembangunan Unud, 5(1), 47-68.

Maemonah, S. (2015). Strategi Pengembangan Industri Kecil Gula Aren Di Kecamatan Limbangan Kabupaten Kendal. Economics Development Analysis Journal, 4(4), 414-426. https://doi.org/10.15294/edaj.v4i4.8704

Nur Irawan, M. R. (2017). Analisis Swot Untuk Menentukan Strategi Kompetitif Pada Pd. Bpr. Bank Daerah Lamongan. Ekonika: Jurnal Ekonomi Universitas Kadiri. https://doi.org/10.30737/ekonika.v2i1.17

Pebrianti, D., \& Muta'ali, L. (2017). Strategi Pengembangan Industri Kerajinan Mutiara Sebagai Daya Tarik Wisata Belanja Di Kota Mataram. Jurnal Bumi Indonesia, 6(3), 1-10.

Permadi, A. (2015). Strategi Pengembangan Industri Kecil Carica. Jejak. https://doi.org/10.15294/jejak.v8i1.3853

Putong, I. (2003). Teknik Pemanfaatan Analisis SWOT Tanpa Skala Industri (ASWOT-TSI). Jurnal Ekonomi \& Bisnis.

Putra, I., \& Ardana, I. (2016). Pengaruh Motivasi Serta Lingkungan Kerja Terhadap Kepuasan Kerja Serta Dampaknya Terhadap Produktivitas Perajin Perak. E-Jurnal Manajemen Universitas Udayana.

Putro, S. W. (2014). Pengaruh Kualitas Layanan dan Kualitas Produk Terhadap Kepuasan Pelanggan dan Loyalitas Kosnumen Restoran Happy Garden 
Surabaya. Jurnal Manajemen Pemasaran, 2(1), 1-9.

Rakhman, A., \& Rahayu, T. S. M. (2017). Pengaruh Kualitas Produk, Promosi Dan Harga Terhadap Keputusan Pembelian Variasi Audio Mobil Di Subur Audio Workshop Purwokerto. Jurnal Manajemen Dan Bisnis MEDIA EKONOMI, 18(1), 33-41.

Rangkuti, F. (2004). Teknik Membedah kasus Bisnis. Analisis SWOT.

Siagian, S. (2002). Kepemimpinan Organisasi \& Perilaku Administrasi. Penerbit Gunung Agung.

Sudana, I. P. (2013). Analisis Pariwisata. Strategi Pengembangan Desa Wisata Ekologis Di Desa Belimbing, Kecamatan Pupuan Kabupaten Tabanan.

Suranta, G. F. (2015). Analisis Strategi Pemasaran Jasa Menghadapi Pesaing. Analisis Strategi Pemasaran Jasa Menghadapi Pesaing.

Warmana, G. O., \& Widnyana, I. W. (2018). Pengaruh Modal Sosial Terhadap KInerja Usaha pada UD. Udiana Desa Celuk, Gianyar, Bali. Jurnal Ekonomi Dan Pariwisata.

Widiastuti. (2013). Analisis SWOT keragaman budaya Indonesia. Jurnal Ilmiah Widya.

Yuniari, W., Yasa, N. N. K., \& Giantari, I. G. A. K. (2018). The Role of Competitive Advantage in Mediating the Influence of Market Orientation on Internationalization and Marketing Performance: A Study on Silver Craft SMEs in Celuk Village, Bali Province. Singaporean Journal of Business Economics and Management Studies. https://doi.org/10.12816/0046860

Yusandipta, N. (2014). Perumusan Strategi Pengembangan Bisnis Usaha Kerajinan Perak Dengan Pendekatan Strength Weakness Opportunity Threat (Swot), Balanced Scorecard Dan Analytical Hierarchy Process (Ahp) (Studi Kasus Di Cv. Moeljodihardjo (Md) Silver, Kotagede, Yogyakarta). UPN Veteran Jakarta.

Zuhri, S. (2013). Analisis Pengembangan Usaha Kecil home Industri Sangkar Ayam Dalam Rangka Pengentasan Kemiskinan. Manajemen Dan Akuntansi. 